\title{
RESISTANCE OF SOME FLAX GENOTYPES TO PODWERY MILDEW AND EFFECT OF THE DISEASE ON YIELD AND YIELD COMPONENTS. \\ Hussein, M. M. M. ${ }^{1}$ and M. R. Omer ${ }^{2}$ \\ ${ }^{1}$ Field Crops Res. Inst., Agric. Res. Center, Giza, Egypt. \\ 2 Plant Pathology Res. Inst., Agric. Res. Center, Giza, Egypt.
}

\begin{abstract}
The present investigation was conducted using twelve flax genotypes namely, Giza 9, Giza 10, Sakha 3, Sakha 4 (local varieties), Jiteka, Blenika, Ilona, Escalina (introduced varieties) and strains 16, 22 and 402//21/10/9 (local strains) grown under field conditions at Tag El-Ezz, El-Dakahlia Governorate during 2010/2011 and 2011/2012 growing seasons. Disease incidence (DI) on the tested genotypes ranged from 44.82 to $90.13 \%$ in the first season and from 38.86 to $81.42 \%$ in the second one. However, disease severity (DS) ranged from 48.83 to $92.25 \%$ in the first season and from 43.83 to $85.85 \%$ in the second season. In general, the local genotypes were more resistant to powdery mildew than the introductions due to their adaptation to the local populations of Oidium lini. Some of the differences between the genotypes in disease incidence and disease severity were inconsistent from season to season, which may indicate the occurrence of genotype $x$ environment interaction. Ilona followed by Giza 9 exceeded the other tested genotypes in straw yield traits. However, Strain 22 followed by Strain 16 outyielded other tested genotypes in seed yield traits. Moreover, other tested genotypes showed intermediate estimates for all straw and seed traits in both seasons. All the significant correlation coefficients between disease intensity variables and agronomic traits were negative in each season, which implies that selection for powdery mildew resistance would necessarily lead to an improvement in agronomic traits and vice versa. On the other hand, many significant correlation coefficients were observed among agronomic traits in each season. Cluster analysis of the twelve genotypes based on dissimilarity in agronomic traits and susceptibility to powdery mildew, placed the fiber type genotypes and the oil type genotypes in two distinct unrelated groups. The genetic background of the fiber type genotypes (dissimilarity level $=15$ ) was more diverse that that of the oil type genotypes (dissimilarity level = almost zero). The diversity of the fiber type genotypes may facilitate the selection process for better agronomic traits and more resistance to powdery mildew.
\end{abstract}

Keywords: Flax (Linum usitatissimum L.) genotypes, powdery mildew, agronomic traits, correlation, cluster analysis.

\section{INTRODUCTION}

Flax (Linum usitatissimum, L.) is one of the oldest fiber crops cultivated for its seeds and fiber production. Flax is grown in Egypt as a dual purpose crop for its seeds and fibers. Fibers obtained from stems are stronger, more durable, and more resistance to moisture than cotton or wool. The fibers are used in textile industry. Seeds are used in animal feed and human food as a source of omega 3-fatty acids. Linseed oil is a good drying oil used mainly for the preparation of paints and varnish. During the winter season, the land is occupied by wheat, clover, and faba bean. Therefore, the extension of the flax cultivated area in marginal soil (saline and sandy) has 
become essential. In the Nile Delta, flax is grown for both fibers and seeds in particular in the northern governorates. This area is characterized by the prevalence of warm wet weather during the late period of flax growing season. Such weather favors epiphytotic spread of powdery mildew disease when virulent isolates of the causal fungus occur. In some countries, the causal fungus of the disease has been recorded as a species of Erysiphe (Nyvall, 1981), but owing to the fact that the perfect stage of this fungus which must be found and identified before the fungus can be referred to as a species of Erysiphe has not been recorded in Egypt, the name of the fungus well be referred to in the present study as that of its imperfect (conidial) stage - Odium lini Škoric (Muskett and Colhoun, 1947), the only form in which it has been found on flax in Egypt. Under Egyptian conditions, owing to the absence of the perfect stage, it is not known for certain how the fungus survives from growing season to season. It may overwinter on volunteer flax or other hosts (Nyvall, 1981). The pathogen infects all aboveground flax organs including stems, leaves, flowers and capsules. Powdery mildew (PM) occurs annually in all flax producing areas in Egypt. Physiological races of the pathogen have not been identified because no differential host lines are available to date. Accurate assessment of losses due to the disease in Egypt has not been reported. However, Aly et al. (1994) found significant negative correlation between disease intensity ratings and agronomic traits (yield and yield components). In India, Pandey and Misra (1993) reported that as the disease increased yield losses increased ranging from 11.8 to $38.9 \%$ and added that yield losses were greater when the disease appears earlier in the season. Perryan and Fitt (2000) reported a substantial yield loss in yield components of flax by powdery mildew disease. Ashry et al. (2002) found that total length/plant was negatively correlated with each of disease incidence and disease severity, while straw yield/plant was negatively correlated only with the disease incidence.

Fungicides are currently the only commercially available management practices for controlling the disease and minimizing associated losses in straw and seed yields (Mansour, 1988 and Aly et al., 1994). Complete dependence on fungicides for the disease control carries risks for the producers, in that accurate coverage and distribution of fungicides may not be achieved and there are potential problems with correct timing of application. Furthermore, increasing concern for the environment will likely mean greater regulation for pesticide usage (Pearc et al., 1996).

Use of cultivars with powdery mildew resistance can resolve all these problems. Therefore, there is a need to improve powdery mildew resistance in flax cultivars through the introgression of resistance gens. Extensive genetic variation for powdery mildew resistance has been identified in some flax populations. For example, Mahto et al. (1995) reported a significant variability among 26 flax genotypes in resistance to powdery mildew, whereas 11 genotypes had above average stability and 7 genotypes of these had high yield. Aly et al. (2001) observed significant differences in the disease occurred between 19 flax genotypes, however some of these differences were inconsistent from one test to another, which may indicate the occurrence of genotype $x$ environment interaction. They also added that most of these 
genotypes did not have satisfactory levels of powdery mildew resistance. Moreover, the powdery mildew resistance, which was expressed by few of these genotypes was environmentally sensitive and most of the significant correlation coefficients between disease intensity variable and agronomic traits were negative, which implies that selection for powdery mildew resistance would necessarily lead to an improvement in agronomic traits and vice versa. Mansour et al. (2003) evaluated 43 flax introductions for powdery mildew resistance under natural infection conditions and observed significant varietal differences in powdery mildew resistance. They also added that selection of the introduction for powdery mildew resistance was based on disease severity (DS) and not disease incidence (DI), because DS was environmentally more stable. Aly et al. (2004) evaluated 8 flax cultivars for powdery mildew resistance under field conditions and concluded that the difference in DS was highly significant $(P<0.01)$ between any cultivar belonging the first group (Dakota, Wilden and Wiliston Brown), which included the resistant cultivars and any cultivar belonging to the second group (Cortland, Linore, C.I. 2008, Giza 7 and Giza 8) which included the susceptible cultivars. Zayed et al. (2008) studied susceptibility of 12 flax genotypes to powdery mildew and effect of the disease on yield and yield components. They concluded that most of the tested flax genotypes did not show any satisfactory level of resistance to the disease, however, Line 420/140/5/11, Line 3 and cultivar Sakha 2 were the least susceptible genotypes. They also added that these genotypes showed superiority in some agronomic traits compared with the other genotypes. The results indicated significant correlations among agronomic traits each year. On the contrarily, nonsignificant associations were observed between disease intensity variables (DI and DS) and agronomic traits. Hussein et al. (2011) evaluated 8 flax cultivars for powdery mildew resistance under field conditions and concluded that the introduced cultivars (C.I. 2008, Cortland and Linor) and the local cultivars (Giza 7 and Giza 8) were highly susceptible, however the introduced cultivars (Williston Brown, Wilden and Dakota) were highly resistant.

Flax genotypes significantly differed in their agronomic traits (Hella et al., 1989; Leilah, 1993; Sharief, 1999; El-kady and Abd-El-Fatah 2009; Mourad et al., 2009; El-Kady et al., 2010; Hussein 2012; El-Refaie and Hussien 2012).

Simple correlation coefficients among flax yield and yield attributes estimated by many investigators (Momtaz et al., 1977; El-Shaer et al., 1983; Aly and Awaad, 1997; Al-Kaddoussi and Moawad 2001; El-kady and Abd-ElFatah 2009; Hussein, 2012; and El-Refaie, and Hussein, 2012).

The main objectives of the present study were gimed 1) estimate powdery mildew resistance or susceptibility of introduced and local genotypes when disease intensity variables i.e., disease incidence (DI) and disease severity (DS) were used as criteria for evaluating resistance or susceptibility, 2) to determine the relationship between disease intensity variables (DI and DS) ratings and agronomic traits (yield and yield attributes) as well as determining the relationships among the agronomic traits, 3) to differentiate among the tested genotypes by using cluster analysis. 


\section{MATERIALS AND METHODS}

Two field experiments were conducted during 2010/2011 and 2011/2012 seasons at Tag El-Ezz Agricultural Research Station, ElDakahliya Governorate, The soil of the experiment was clay in texture with organic matter of 1.6 and $1.9 \%, \mathrm{pH}$ of 7.9 and 7.6 and $\mathrm{EC}(\mathrm{ds} / \mathrm{cm})$ of 4.9 and 5.2 in the first and second season, respectively. The experimental fields were well prepared. Each experiment consisted of a randomized complete blocks design of four replicates (blocks) in each season. Plot size was $2 \times 3 \mathrm{~m} \mathrm{(6} \mathrm{\textrm {m } ^ { 2 } )}$ consisted of 20 rows. Seeds of the tested genotypes (Table 1) were hand drilled into rows $10 \mathrm{~cm}$ apart at seedling rate of $50 \mathrm{~kg}$ seeds/fed for the local and introduced flax varieties, $60 \mathrm{~kg}$ seeds/fed for the promising local strains 16 and 22 and $70 \mathrm{~kg}$ seeds/fed for the local strain 402/11/10/9. Weeds were mechanically controlled after 20 days from sowing. Planting dates were $20^{\text {th }}$ and $15^{\text {th }}$ November in the first and second season. Seeds of the twelve tested flax genotypes were obtain from Fiber Crops Research Section, Field Crops Research Institute, Agricultural Research Center. Recommended P and K fertilizers were pre-sowing added fully at the rate of $100 \mathrm{~kg} / \mathrm{fed}$ calcium superphosphate $\left(15.5 \% \mathrm{P}_{2} \mathrm{O}_{5}\right)$ and $50 \mathrm{~kg} / \mathrm{fed}$ potassium sulphate $(48.5 \%$ $\mathrm{K}_{2} \mathrm{O}$ ). Mineral nitrogen fertilizer at the rate of $45 \mathrm{~kg} / \mathrm{fed}$ in the form of ammonium nitrate $(33.5 \% \mathrm{~N})$ was applied in two equal doses, the first dose was added before the first irrigation and after weed control, while the second was applied before the second irrigation. Flooding irrigation was used in the two seasons of the experimentation. All other agricultural practices for growing flax were conducted as recommended for the region. Powdery mildew (PM) was allowed to develop naturally. Disease incidence (DI) and disease severity (DS) were rated visually on 20 April in the first season and on 25 April in the second one. Disease incidence was measured as percentage of infected plants in a random sample of 50 plants/plot. However, disease severity was measured as percentage of infected leaves/plant in a random samples of 10 plant/plot (Nutter et al., 1991). The twelve tested flax genotypes differed in their origin and purpose. Origin and purpose of these genotypes are shown in Table (1). The preceding crop was rice (Oryza sativa L.) in the first season and maize (Zea mays, L.) in the second season.

At full maturity, ten guarded plants in each experimental unit in the four replications were hand pulled carefully at random to determine the folliwng yield components, however seed, straw and fiber yields/fed were estimated from an area of $3.6 \mathrm{~m}^{2}$ from the central area of each plot and then the yields of seed, straw and fiber yields/fed were calculated. On the other hand, retting process made in Fiber Crops Research Institute, Agricultural Research Center to extract flax fiber for studying its quantity and quality parameters. The studied agronomic and technological traits were as follows: 
Table (1). Origin, type, and pedigree of flax genotypes used in the present study.

\begin{tabular}{|c|c|c|c|c|}
\hline No. & Genotypes & Origin & Type & Pedigree \\
\hline 1 & Giza 9 & Local variety & Fiber & L. $420 \times$ Bombay \\
\hline 2 & Giza 10 & Local variety & Fiber & L. $420 \times$ Bombay \\
\hline 3 & Sakha 3 & Local variety & Fiber & Blenika (2E) x 1.2096 \\
\hline 4 & Sakha 4 & Local variety & Fiber & Blenika (R3) x 1.2096 \\
\hline 5 & Jiteka & $\begin{array}{l}\text { Introduced } \\
\text { Czech }\end{array}$ & Fiber & Introduction \\
\hline 6 & Blenika & $\begin{array}{l}\text { Introduced } \\
\text { Holland }\end{array}$ & Fiber & Introduction \\
\hline 7 & Escalina & $\begin{array}{l}\text { Introduced } \\
\text { Holland }\end{array}$ & Fiber & Introduction \\
\hline 8 & Ilona & $\begin{array}{l}\text { Introduced } \\
\text { Holland }\end{array}$ & Fiber & Introduction \\
\hline 9 & Gentiana & $\begin{array}{l}\text { Introduced } \\
\text { Romania }\end{array}$ & Oil & Introduction \\
\hline 10 & Strain 16 & Local strain & Oil & Giza 8 x Strain 2419/1 \\
\hline 11 & Strain 22 & Local strain & Oil & $1.370 \times 1.2561$ \\
\hline 12 & \begin{tabular}{|l|} 
Strain \\
$402 / 21 / 10 / 9$
\end{tabular} & Local strain & Oil & Giza 5 x 1.235 (USA) \\
\hline
\end{tabular}

\section{A. Straw yield and its attributes:}

1.Total length/plant $(\mathrm{cm})$ : Plant height from the coyledonary node to the apical bud of each plant.

2.Technical stem length $(\mathrm{cm})$ : The length of the main stem from the cotyledonary node to the first or lowest first or lowest branching point.

3.Straw yield/plant $(\mathrm{g})$ : Weight of the mature air-dried straw per plant after removing the capsule as an average.

4.Straw yield/fed (ton): Estimated based on the area of the whole plot

5 .Fiber yield/plant (g): Weight of ten fiber ribbons (bundles) from each plot.

6. Fiber yield/fed (ton): Estimated based on the area of the whole plot after retting.

7.Long fiber percentage (\%):It was estimated as follows:

Long fiber $\%=\frac{\text { The long fiber yield/fed }}{\text { The retted straw yield/fed }} \times 100$

8. Fiber length $(\mathrm{cm})$ : It was measured as an average of ten fiber ribbons (bundles) from each plot.

9. Fiber fineness (Nm): It was determined according to Radwan and Momtaz (1966) as follows:

$\mathrm{Nm}=(\mathrm{N} \times \mathrm{L}) / \mathrm{G}$, where $\mathrm{Nm}=$ number of material,

$\mathrm{N}=$ number of fibers (20 fibers)

$\mathrm{L}=$ Length of fibers in $\mathrm{mm}$

$\mathrm{G}=$ weight of fibers in $\mathrm{mg}$.

B. Seed yield and its attributes:

1.Number of apical branches: Total number of apical branches of the plant.

2.Number of capsules/plant: Number of harvested capsules per plant.

3.Number of seeds/capsule: Number of harvested seeds per capsules. 
4.Seed index (g): Weight of 1000 seeds in $\mathrm{g}$.

5.Seed yield/plant $(\mathrm{g})$ : Weight of harvested seeds per plant.

6.Seed yield/fed $(\mathrm{kg})$ : Estimated based on the area of the whole plot.

7. Seed oil percentage (\%) It was determined as described by the A.O.A.C method (1995) using a Soxhlet apparatus and petroleum ether $\left(60-80^{\circ} \mathrm{C}\right)$ as a solvent.

8. Oil yield/fed $(\mathrm{kg})$ : It was determined by multiplying seed yield/fed $\mathrm{x}$ seed oil percentage.

Statistical analysis:

Analysis of variance (ANOVA) of the data was performed on agronomic traits and disease intensity variables to determine genotype effect according to Gomez and Gomez (1984). The experimental design was a randomized complete block. Mean comparison for variable were made among the twelve tested genotypes by using Least Significant Difference (LSD) at 5 and 1\% levels of probability. Person's correlation coefficient was used to evaluate the degree of association between disease intensity variables (DI and DS) and agronomic traits as well as to evaluate the degree of association among agronomic traits. Moreover cluster analysis can be used to identify and differentiate among genptypes with similar adaption. All statistical analyses were performed using the computer software package MSTAT-C.

\section{RESULTS AND DISCUSSION}

\section{Evaluation of flax genotypes for PM resistance}

The present study was performed in 2010/2011 and 2011/2012 growing seasons (hereafter referred to as year 2011 and 2012, respectively) to evaluate resistance of twelve genotypes to powdery mildew under natural infection conditions in saline soils. Among these twelve tested genotypes, seven were local genotypes (four local varieties and three strains), while the other five genotypes introduced from three countries namely, Czech, Holland and Romania. The twelve tested flax genotypes were Giza 9, Giza 10, Sakha 3 and Sakha 4 (local varieties), Jiteka, Blenika, Escalina, llona, and Gentiana (introduced varieties), in addition to strains 16, 22 and 402/21/10/9 (local strains).

The precision of field evaluation of genetic resistance to PM affected by environmental variation and heterogeneous levels of natural inoculum. Agronomic traits and disease intensity variables (DI and DS) were used as criteria for evaluating the tested flax genotypes. Results in Table (2) revealed that the differences among the genotypes in DI and DS were significant or highly source of variation among the tested genotypes each year indicating that extensive genetic variation for DI and DS was found among the tested genotypes. Therefore, it seems reasonable to conclude that environmental conditions and levels of inoculumn in 2011 and 2012 were favorable for epiphytotic spread of the disease. As shown in Table (2), disease incidence ratings ranged from 44.82 to $90.13 \%$ in 2011 and from 38.86 to $81.42 \%$ in 2012. However, disease severity ratings ranged from 48.83 to $92.25 \%$ in 2011 and from 43.83 to $85.85 \%$ in 2012. Mean percentage of DI on the local genotypes (Giza 9, Giza 10, Sakha 3, Sakha 4, Strain 10, strain 22 and Strain 
402/21/10/9) was 49.80 in 2011 and 43.07 in 2012, while the mean percentage of DI on the introductions was 71.21 in 2011 and 62.18 in 2012. The same trend was observed regarding DS, which was 56.28 and 50.71 on the local genotypes in 2011 and 2012, respectively, while DS was 77.88 and $69.34 \%$ in the introductions in 2011 and 2012, respectively. These results suggest that in general, the local genotypes were more resistant to PM than the introduction. This resistance could be attributed to the adaptation of the local genotypes to the local populations of $O$. lini. On the other hand, the introductions seem to be less adapted and hence more susceptible. Within the local genotypes, strain 16 was always more resistant to PM than strain 22.

Table (2). Powdery mildew intensity variables (DI) and DS) for the tested flax genotypes under field conditions in Tag EI-Ezz, EIDakahlia in 2010/2011 and 2011/2012.

\begin{tabular}{|l|c|c|c|c|}
\hline \multirow{2}{*}{ Genotype } & \multicolumn{2}{|c|}{$\mathbf{2 0 1 0 / 2 0 1 1}$} & \multicolumn{2}{c|}{$\mathbf{2 0 1 1 / 2 0 1 2}$} \\
\cline { 2 - 5 } & $\begin{array}{c}\text { Disease } \\
\text { incidence } \\
\text { (DI) \% }\end{array}$ & $\begin{array}{c}\text { Disease } \\
\text { Severity } \\
\text { (DS) \% }\end{array}$ & $\begin{array}{c}\text { Disease } \\
\text { incidence } \\
\text { (DI) \% }\end{array}$ & $\begin{array}{c}\text { Disease } \\
\text { Severity } \\
\text { (DS) \% }\end{array}$ \\
\hline Giza 9 & $45.91^{a}$ & 49.90 & 39.36 & 44.67 \\
Giza 10 & 52.61 & 58.17 & 40.53 & 46.92 \\
Sakha 3 & 44.82 & 48.83 & 38.86 & 43.83 \\
Sakha 4 & 47.12 & 49.23 & 39.28 & 47.08 \\
Jiteka & 89.29 & 91.77 & 78.16 & 82.87 \\
Blenika & 90.13 & 92.25 & 81.42 & 85.85 \\
Escalina & 73.52 & 81.23 & 65.52 & 70.72 \\
llona & 47.35 & 56.42 & 39.35 & 54.08 \\
Gentiana & 55.74 & 67.71 & 46.44 & 53.17 \\
Strain 16 & 44.55 & 50.92 & 36.72 & 44.75 \\
Strain 22 & 56.95 & 66.00 & 52.78 & 63.33 \\
Strain 402/21/10/9 & 56.62 & 70.92 & 53.96 & 64.37 \\
\hline LSD (P $\leq 0.05)$ & 4.35 & 5.08 & 3.86 & 4.62 \\
LSD (P $\leq 0.01)$ & 5.86 & 6.90 & 4.94 & 5.28 \\
\hline
\end{tabular}

a Mean of four replications.

Some of the differences between the genotypes in DI or DS were inconsistent from season to season, which may indicate the occurrence of genotype $x$ environment interaction, for example, the differences between Giza 9 and Giza 10 in DI and DS were highly significant in 2011, while they were nonsignificant in 2012. Similarly, the difference in DS between Escalina and Gentiana was highly significant in 2011 while it was nonsignificant in 2012. These results imply that successful screening of flax genotypes for PM resistance requires testing the genotypes in as many seasons as possible as this would give more accurate assessment of their resistance level.

\section{Evaluation of flax genotypes for agronomic traits:}

\section{a. Straw yield and its attributes:}

Results of the analysis of variance (Table 3 ) detected significant differences among the tested flax genotypes for all straw yield traits i.e. total length/plant, technical stem length, plant straw yield/plant, straw yield/fed, fiber yield/plant, fiber yield/fed, long fiber percentage, fiber length and fiber 
fineness in both seasons, indicating the presence of considerable amount of genetic variability. Ilona variety followed by Giza 9 variety surpassed the other tested flax genotypes in all straw traits. However, the local strains gave the lowest values of the previous traits in both seasons. Ilona variety exceeded strain 22 by 45.10, 42.49, 45.29, 46.06, 140.36, 119.11, 29.08, 28.01, 179.79, $147.46,49.72,43.80,16.01,12.31,31.81,36.60,88.87$ and $85.04 \%$ for the abovementioned traits in the first and second seasons, respectively. On the other hand, the other tested flax genotypes recorded intermediate estimates for straw yield traits. The differences between the twelve flax genotypes in different straw yield traits may be attributed to genetical factors.

Similar conclusions were reported by Hella et al. (1989), Leilah (1993), Sharief (1999), Mourad et al. (2009), El-Kady et al. (2010), Hussein (2012) and El-kady and Abd-El-Fatah 2009; El-Refaie and Hussein (2012).

\section{b. Seed yield and its attributes}

Differences among the twelve tested flax genotypes in seed yield traits are shown in Table (4). Analysis of variance revealed that flax genotypes differed significantly in seed yield traits i.e. number of apical branches/plant, number of capsules/plant, number of seeds/capsules, seed index, seed yield/plant, seed yield/fed, seed oil percentage and oil yield/fed in both seasons. The local strain 22 followed by Strain 16 and Gentiana variety outyielded the other tested flax genotypes in seed yield traits in the two seasons. However, Escalina variety, followed by Jiteka and Sakha 3 gave the lowest seed yield traits. Other tested genotypes recorded intermediate estimates for seed yield traits in both seasons. The local Strain 22 exceeded introduced variety Escalina by $58.79,68.48,75.33,88.93,48.34,56.78$, $90.38,83.59,100.75,94.64,151.05,172.11,41.56,39.97,255.40$ and $280.89 \%$ for the previous traits in the first and second seasons, respectively. The differences between the twelve tested flax genotypes in seed yield traits could be attributed to the genetical background. These results are in agreement with those reported by several investigators (Hella et al., (1989); Leileh, (1993); Sharief, (1999); El-kady and Abd-El-Fatah (2009); Mourad et al., (2009); El-Kady et al.,(2010); Hussein, (2012) and Amany El-Refaie and Hussein, (2012). 
Table (3). Straw yield and its attributes for twelve flax genotypes infected with powdery mildew under field conditions in Tag El-Ezz, El-Dakahlia in 2010/2011 and 2011/2012 seasons.

\begin{tabular}{|c|c|c|c|c|c|c|c|c|c|}
\hline Genotypes & 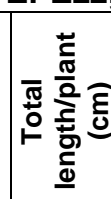 & 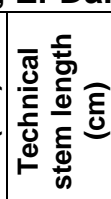 & 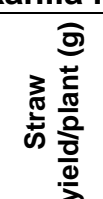 & 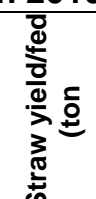 & 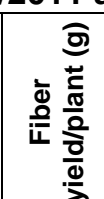 & 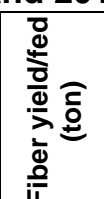 & 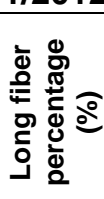 & 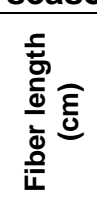 & 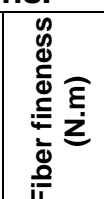 \\
\hline \multicolumn{10}{|c|}{ 2010/2011 season } \\
\hline za 9 & 96.86 & 45 & 1.312 & 4.109 & 0.229 & 716 & .42 & .45 & 1.88 \\
\hline za & & & 92 & & 225 & & & & \\
\hline ak & & & 1.175 & 3.470 & 0.204 & 88 & & 78.14 & 63.12 \\
\hline$k$ & & & & 3.962 & 0.175 & & & & \\
\hline tek & & 72. & 0.866 & 3.913 & 0.142 & 0.639 & & 72.66 & 245.16 \\
\hline en & & 71 & & & 0.122 & & & & 221.46 \\
\hline Esca & & 74.82 & 0.985 & 3.916 & 0.165 & 0.654 & & 4.11 & 257.15 \\
\hline $\begin{array}{ll}0 \\
\end{array}$ & & & 1.483 & & 0.263 & 0.792 & & 2.33 & 298.73 \\
\hline Gent & & & 0.686 & 1 & 0.109 & 0.551 & & 2.55 & 186.26 \\
\hline & & & & & & & & 55.22 & 19 \\
\hline Strain 22 & 66.90 & 57.80 & 0.617 & 3.459 & 0.094 & 9 & & 62.46 & 158.17 \\
\hline $\begin{array}{l}\text { Strain } \\
402 / 21 / 10 / 9\end{array}$ & 82.92 & 70.43 & 1.364 & 3.706 & 0.236 & 0.643 & 17.12 & 69.48 & 160.2 \\
\hline $\begin{array}{ll}\mathrm{LSD} & (\mathrm{P} \\
0.05) & \end{array}$ & 76 & 323 & 253 & 2 & 45 & 34 & 0.52 & 73 & 16.20 \\
\hline $\begin{array}{ll}\text { LSD } & (P \\
0.01)\end{array}$ & 7.69 & 4.34 & 0.340 & 0.553 & 0.061 & 0.156 & 0.70 & 5.33 & 18.33 \\
\hline \multicolumn{10}{|c|}{ 2011/2012 season } \\
\hline aiza & & & .362 & 4.350 & 0.249 & 95 & 28 & .33 & 5.83 \\
\hline & & & & & & & & & \\
\hline & & & & & & & & & \\
\hline Sakt & & 77. & 1.2 & 202 & 4 & 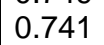 & & 5 & 26 \\
\hline & & & & & & & & & \\
\hline le & & 73 & & & 8 & 59 & 16 & 74 & 22 \\
\hline & & & & & & & & & \\
\hline Ilona & & & & & 0.292 & 0.847 & & 87.48 & 302.7 \\
\hline Gent & & & & & & & & & \\
\hline Stra & & & 0. & 5 & 0.132 & 0. & 16.66 & 33 & 19 \\
\hline \multirow{2}{*}{$\begin{array}{l}\text { Strain } 22 \\
\text { Strain } \\
402 / 21 / 10 / 9\end{array}$} & & & 0.722 & & 0.118 & 0.589 & 16.41 & 64.04 & 163.46 \\
\hline & 84.78 & 72.48 & 1.448 & 3.812 & 0.256 & 0.675 & 17.71 & 72.18 & 176.93 \\
\hline $\begin{array}{ll}\overline{L S D} & (\mathrm{P} \\
0.05)\end{array}$ & 6.07 & 4.17 & 0.284 & 0.484 & 0.075 & 0.164 & 0.54 & 3.92 & 19.18 \\
\hline $\begin{array}{ll}\text { LSD } & (P \\
0.01)\end{array}$ & 8. & 5.60 & 0.382 & 0.582 & 0.091 & 0.186 & 0.73 & 5.26 & 22.61 \\
\hline
\end{tabular}


Hussein, M. M. M. and M. R. Omer

Table (4). Seed yield and its attributes for twelve flax genotypes infected with powdery mildew under field conditions in Tag El-Ezz, ElDakahlia in 2010/2011 and 2011/2012 seasons.

\begin{tabular}{|c|c|c|c|c|c|c|c|c|}
\hline Genotypes & 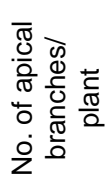 & 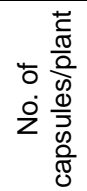 & 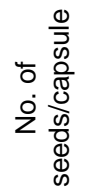 & 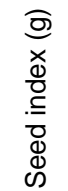 & 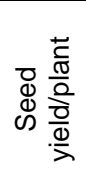 & 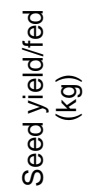 & $\begin{array}{l}\frac{0}{0} \\
\overline{\overline{0}} \\
\overline{0} \\
\overline{0} \\
\infty\end{array}$ & $\begin{array}{l}\frac{0}{d} \\
\frac{d}{0} \\
\frac{0}{0} \\
\frac{1}{x} \stackrel{5}{=} \\
\frac{0}{0}\end{array}$ \\
\hline \multicolumn{9}{|c|}{$2010 / 2011$ season } \\
\hline Giza 9 & 13.53 & 10.70 & 8.48 & 6.35 & 0.516 & 436.88 & 38.84 & 169.68 \\
\hline Giza 10 & 13.95 & 11.40 & 8.83 & 6.62 & 0.539 & 460.93 & 39.22 & 180.78 \\
\hline Sakha 3 & 12.95 & 10.25 & 8.40 & 6.13 & 0.462 & 375.20 & 38.15 & 143.14 \\
\hline Sakha 4 & 13.15 & 10.28 & 8.72 & 6.25 & 0.486 & 420.78 & 38.66 & 162.67 \\
\hline Jiteka & 10.30 & 8.43 & 7.60 & 4.28 & 0.348 & 246.57 & 36.66 & 90.39 \\
\hline Blenika & 11.45 & 9.26 & 7.78 & 4.78 & 0.387 & 310.72 & 35.27 & 109.59 \\
\hline Escalina & 9.73 & 7.50 & 6.64 & 3.64 & 0.402 & 240.18 & 33.88 & 81.37 \\
\hline Ilona & 12.73 & 9.45 & 8.35 & 5.55 & 0.449 & 364.16 & 37.16 & 135.32 \\
\hline Gentiana & 14.05 & 11.48 & 8.95 & 6.76 & 0.563 & 468.96 & 39.55 & 191.48 \\
\hline Strain 16 & 14.45 & 11.68 & 9.38 & 6.83 & 0.621 & 577.43 & 41.28 & 238.36 \\
\hline Strain 22 & 15.45 & 13.15 & 9.85 & 6.93 & 0.807 & 602.98 & 47.96 & 289.19 \\
\hline $\begin{array}{l}\text { Strain } \\
402 / 21 / 10 / 9\end{array}$ & 13.92 & 10.75 & 8.45 & 7.18 & 0.657 & 544.90 & 39.55 & 215.51 \\
\hline $\operatorname{LSD}(P<0.05)$ & 1.82 & 1.42 & 1.21 & 0.71 & 0.079 & 77.05 & 0.83 & 31.59 \\
\hline LSD $(P<0.01)$ & 2.44 & 1.73 & 2.63 & 1.09 & 0.106 & 103.50 & 1.10 & 42.44 \\
\hline \multicolumn{9}{|c|}{$2011 / 2012$ season } \\
\hline Giza 9 & 13.99 & 13.71 & 9.58 & 6.54 & 0.642 & 526.37 & 39.12 & 205.52 \\
\hline Giza 10 & 14.69 & 14.01 & 9.88 & 6.95 & 0.674 & 583.26 & 39.36 & 229.57 \\
\hline Sakha 3 & 13.88 & 13.56 & 8.94 & 6.30 & 0.594 & 442.53 & 37.88 & 167.63 \\
\hline Sakha 4 & 14.34 & 13.65 & 9.06 & 6.46 & 0.623 & 494.92 & 38.95 & 192.77 \\
\hline Jiteka & 11.63 & 9.43 & 7.89 & 4.76 & 0.384 & 299.34 & 36.95 & 110.61 \\
\hline Blenika & 12.81 & 10.07 & 8.48 & 5.20 & 0.419 & 401.36 & 37.18 & 149.23 \\
\hline Escalina & 10.50 & 8.04 & 7.01 & 3.90 & 0.448 & 258.09 & 34.90 & 90.09 \\
\hline Ilona & 13.75 & 11.95 & 8.63 & 5.59 & 0.513 & 419.48 & 37.75 & 158.35 \\
\hline Gentiana & 15.70 & 14.35 & 9.93 & 7.36 & 0.723 & 663.09 & 41.52 & 275.31 \\
\hline Strain 16 & 15.98 & 14.64 & 10.18 & 7.40 & 0.759 & 672.72 & 42.24 & 284.16 \\
\hline Strain 22 & 17.69 & 15.19 & 10.99 & 7.76 & 0.872 & 702.29 & 48.85 & 343.07 \\
\hline $\begin{array}{l}\text { Strain } \\
402 / 21 / 10 / 9\end{array}$ & 14.43 & 11.95 & 9.13 & 7.62 & 0.759 & 647.44 & 40.38 & 261.44 \\
\hline LSD $(P<0.05)$ & 2.21 & 1.64 & 1.53 & 0.84 & 0.114 & 88.72 & 1.15 & 35.71 \\
\hline LSD $(P<0.01)$ & 2.97 & 2.20 & 1.72 & 1.12 & 0.136 & 108.89 & 1.55 & 44.54 \\
\hline
\end{tabular}

\section{Correlation coefficient study}

The correlation coefficient is one of the most important measurements for the degree of association between any two traits; thus, it is applied in plant breeding programs. Correlation coefficient between yield and yield components varying in magnitude and direction were reported in different flax yield studies.

\section{a.Correlation coefficient between PM intensity variables agronomic traits}

Correlation coefficients for powdery mildew intensity variables (DI and DS) and agronomic traits (straw and seed yields and their attributes) for twelve tested flax genotypes under field conditions in Tag El-Ezz Research Station, Dakahlia Governorate during 2010/2011 and 2011/2012 seasons are presented in Table 5. It well known that the type and degree of correlation 
between traits may facilitate the selection process in breeding program. Selection for any trait may result in an improvement or deterioration in other traits according to the type and the degree of association between traits. In this study, all of the significant coefficients between disease intensity variables and agronomic traits were negative (Table 5), which implies that selection for powdery mildew (PM) resistance would necessarily lead to an improvement in agronomic traits and vice versa. The negative correlation, also indicate deterioration in most of the agronomic traits due to the occurance of PM. This negative correlation between disease intensity variables (DI and DS) and agronomic traits was previously reported by Aly et al. (1994 and 2002).

Table (5). Correlation coefficients for powdery mildew intensity variables and agronomic traits for twelve flax genotypes under field conditions in Tag El-Ezz, El-Dakahlia in 2010/2011 and 2011/2012 seasons.

\begin{tabular}{|c|c|c|c|c|}
\hline \multirow[b]{2}{*}{ Agronomic traits } & \multicolumn{2}{|c|}{$2010 / 2011$} & \multicolumn{2}{|c|}{$2011 / 2012$} \\
\hline & \begin{tabular}{|c|} 
Diseases \\
incidence \% \\
$(n=12)$
\end{tabular} & $\begin{array}{c}\text { Disease } \\
\text { severity \% } \\
(n=12)\end{array}$ & $\begin{array}{c}\text { Diseases } \\
\text { incidence \% } \\
(n=12)\end{array}$ & $\begin{array}{c}\text { Disease } \\
\text { severity \% } \\
(n=12)\end{array}$ \\
\hline Total length/plant (cm) & $-0.752^{\star \star a}$ & $-0.851^{* *}$ & $-0.743^{\star \star}$ & $-0.841^{\star \star}$ \\
\hline $\begin{array}{l}\text { Technical stem length } \\
(\mathrm{cm})\end{array}$ & $-0.803^{\star *}$ & $-0.837^{\star \star}$ & $-0.718^{\star *}$ & $-0.834^{\star *}$ \\
\hline Straw yield/plant (gm) & $-0.643^{*}$ & $-0.790^{* *}$ & -0.556 & $-0.770^{* *}$ \\
\hline Straw yield/fed (ton) & $-0.632^{*}$ & $-0.725^{\star \star}$ & -0.515 & $-0.712^{\star \star}$ \\
\hline Fiber yield/plant $(\mathrm{g})$ & $-0.745^{\star \star}$ & $-0.747^{\star *}$ & $-0.679 *$ & $-0.652^{*}$ \\
\hline Fiber yield/fed (ton) & $-0.642^{*}$ & $-0.754^{*}$ & $-0.632^{*}$ & $-0.730^{\star *}$ \\
\hline $\begin{array}{l}\text { Long fiber percentage } \\
(\%)\end{array}$ & -0.512 & $-0.566^{*}$ & -0.502 & $-0.549^{*}$ \\
\hline Fiber length (cm) & -0.420 & -0.424 & -0.353 & -0.381 \\
\hline Fiber fineness (N.m) & -0.452 & $-0.618^{*}$ & -0.372 & $-0.601^{*}$ \\
\hline $\begin{array}{l}\text { Number of apical } \\
\text { branches }\end{array}$ & $-0.813^{* *}$ & $-0.808^{* *}$ & $-0.751^{\star *}$ & $-0.807^{* *}$ \\
\hline Number of capsules/plant & $-0.725^{\star *}$ & $-0.833^{* *}$ & $-0.653^{*}$ & $-0.827^{\star \star}$ \\
\hline Number of seeds/capsule & $-0.716^{\star *}$ & $-0.840^{\star *}$ & $-0.613^{*}$ & $-0.825^{\star \star}$ \\
\hline Seed index $(g)$ & $-0.706^{\star *}$ & $-0.826^{\star *}$ & $-0.626^{*}$ & $-0.818^{\star *}$ \\
\hline Seed yield/plant $(\mathrm{g})$ & -0.390 & -0.485 & -0.320 & -0.340 \\
\hline Seed yield/fed $(\mathrm{kg})$ & -0.430 & -0.395 & -0.311 & -0.278 \\
\hline Seed oil percentage (\%) & -0.344 & -0.406 & -0.324 & -0.401 \\
\hline Oil yield/fed $(\mathrm{kq})$ & -0.385 & -0.401 & -0.334 & -0.359 \\
\hline
\end{tabular}

a.Linear correlation coefficient between disease intensity variables and the designated agronomic traits. Linear correlation coefficient is significant at $P<0.05\left(^{*}\right)$ or $P<0.01\left(^{\star \star}\right)$.

\section{b. Correlation coefficient among agronomic traits:}

Simple correlation coefficients between straw and seed yields and their attributed variables for twelve tested flax genotypes infected with powdery mildew under field conditions in 2010/2011 and 2011/2012 seasons are presented in Tables 6 .I $t$ is evident that straw yield/fed, positively and significantly correlated with its attributed variables i.e. total and technical stem length/plant, straw and fiber yields/plant, fiber length and fineness. However, positive and insignificant 
association was found between straw yield/fed and each of straw yield/plant and long fiber percentage. Moreover, negative and insignificant association was observed between straw yield/fed and each of technical stem length, fiber yield/plant, number of apical branches and capsules/plant, number of seeds/capsule, seed index, seed yield/plant, seed and oil yields/fed and seed oil percentage. Similarly, seed yield/fed positively and significantly correlated with its attributed variables i.e. number of apical branches and capsules/plant, number of seeds/capsule, seed index, seed yield/plant, seed oil percentage and oil yield/fed. However, a positive and insignificant association was found between seed index and seed oil percentage. Other seed yield attributes were positively and significantly correlated with each other. Similar trend was observed for straw and seed yields and their attributed variables (agronomic traits) in 2011/2012 season (Table 7). Similar findings were reported by Momtaz et al. (1977), El-Shaer et al. (1983), Aly and Awaad (1997), Sharief (1999), Al-kaddoussi and Moawad (2001) El-kady and Abd-El-Fatah 2009; EL-Refaie and Hussein (2012).

\section{Cluster analysis study}

Cluster analysis can be used to identify cultivars with similar adaption which can be useful for sampling in subsequent studies and parental selection in hybridization breeding programs.

Cluster analysis was applied to illustrate relative genetic distance and genetic divergence within a given germplasm base..

A phenogram based on average linkage cluster analysis of twelve flax genotypes based on dissimilarity in their agronomic traits and susceptibility to O. lini are presented in Fig. 1.

As shown in Fig. 1, the phenogram separated the twelve flax genotypes into three main groups, six of flax varieties i.e. Giza 10, Sakha 4, Escalina, Giza 9, Sakha 3 and Blenika were placed in the first group (dissimilarly level $=2.5$ ), while the flax varieties Jiteka and llona were placed in the second group (dissimilarly level $=5$ ) and the flax variety Gentiana and the promising strains 1622 and 402/20/10/9 were placed in the third group (dissimilarity level $=$ almost zero). The flax genotypes of the first and the second group were classified as a fiber type that characterized by an increase in straw yield traits. On the other hand, the flax genotypes of the third group were classified as an oil type that characterized by an increase in seed yield traits.

These results suggest that the genetic background of the fiber type genotypes (dissimilarly level $=15$ ) is more diverse compared with that of the oil type genotypes (dissimilarly level = almost zero). The diversity of fiber type genotypes may facilitate the selection process for better agronomic traits and more resistance to $\mathrm{PM}$. 
J. Plant Production, Mansoura Univ., Vol. 4 (1), January, 2013 6 
Hussein, M. M. M. and M. R. Omer

7 


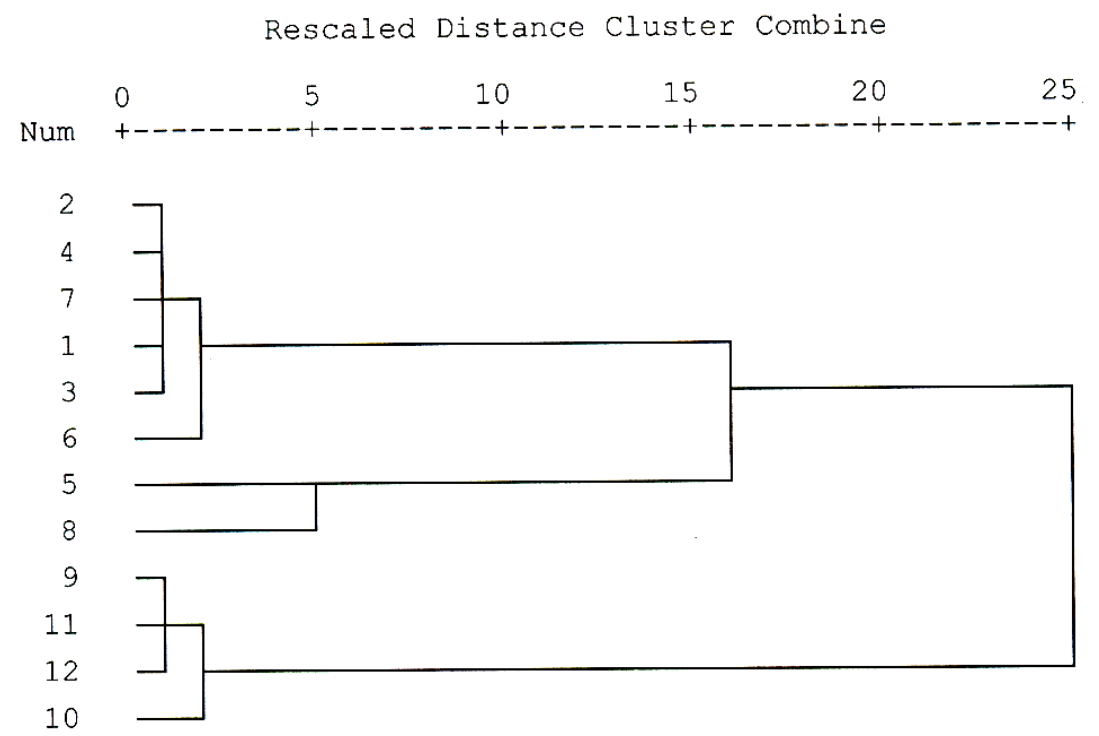

Fig. (1): Phenogram based on average linkage cluster analysis of flax genotypes based on their agronomic traits and susceptibility to powdery mildew. The tested genotypes were Giza 9 (1), Giza 10 (2), Sakha 3 (3), Sakha 4 (4), Jiteka (5), Blenika (6), Escalina (7), Ilona (8), Gentiana (9), Strain 16 (10), Strain 22 (11), and Strain 402/21/10/9 (12).

\section{REFERENCES}

Al-Kaddoussi, A.R. and E.A. Moawad (2001). Yield analysis of seed and straw yield components under three row spacing for some genotypes of flax (Linum usitatissimum, L.). Egypt. J. Appl. Sci., 16 (21): 426-441.

Aly, A.A.; Amna, H.H. El-Sweify and M.T.M. Mansour (2001). Evaluation of some flax genotypes for powdery mildew resistance under greenhouse and field conditions. J. Agric. Sci., Mansoura Univ., 27 (11): $7322-7333$.

Aly, A.A.; A.Z.A. Ashour, E.A.F. El-Kady and M.A. Mostafa (1994). Effectiveness of fungicides for control of powdery mildew of flax and effect of the disease on yield and yield components. J. Agric. Sci., Mansoura Univ., 19: 4383-4393.

Aly, A.A., Maggie E.M. Hassan, E.M. Hussein and M.T.M. Mansour (2004) Quantification of flax resistance to powdery mildew by the random amplified polymeric DNA (RAPD). Egypt. J. Agric. Res., 82 (4): 14991508.

Aly, R.M. and H.A. Awaad (1997). Yield ability and yield analysis of some flax genotypes grown under different sowing dates in sandy soils. Zagazig J. Agric. Res., 24 (2): 199-211.

A.O.A.C. (1995). Official methods of Analysis. $16^{\text {th }}$ Ed. Association of Official Analytical Chemists. Washington, DC, USA. 
Ashry, N.A., M.T.A. Mansour, A.A. Aly and S.M.E. Zayed (2002). Genetic studies on powdery mildew resistance of flax, yield, and some yield components. Egypt. J. Agric. Res., 80 (4): 1525-1537.

El-kady, Eman,AE and AAE Abd-El-Fatah (2009) Comparison of yield, its complements', physical of twelve flax genotypes and chemical composition of twelve flax genotypes. J. Agric. Res. Kafere El-Sheikh Univ. 35: 69-85.

El-Kady, E.A.F., M.E.A. Kineber, S.H.A. Mostafa, A.M. Hella, Eman A.E. ElKady, A.A. Abdel-Fatah, T.A. Abou-Zaied, I.E. El-Deeb, A.M. Mousa, S.Z.A. Zedan, H.M.H. Abo-Kaied, E.E. Lotfy, A.M.A. El-Azzouni, A.A. El-Gazzar, G.H. El-Shimy, Amna H.H. El-Sweify, Amany M.M. ElRefaie, T.A. Omar, Afaf E.A. Zahana, E.A. Moawad, N.K.M. Mourad, T. Nasr El-Din, S.M.S. Gaafar, M. El-Farouk, M.M.M. Hussein and Sanai S. Hassan (2010). Studies in stability in two new flax varieties Sakha 3 and Sakha 4. J. Agric. Res., Kafr El-Sheikh Univ., 36 (2): 182-192.

El-Refaie Amany M.M. and M.M.M. Hussein (2012). Combining ability estimates in F2 flax populations for some quantitative traits under normal and saline soil conditions. J. Plant Production, Mansoura Univ., 3 (7): 2107-2122.

El-Shaer, M.H., A. Momtaz, M.M. Samia and A.M. Hella (1983). The association among straw, seed and fiber yields, and other characters in flax grown at Giza, A.R.E. Ann. Agric. Sci., Moshtohor, 20: 195-209.

Gomez, K.A. and A.A. Gomez (1984). Statistical Procedures for Agricultural Researches. John Wiley Sons. Inc., New York.

Hella, A.M.A., N.K.M. Mourad and E.A.F. El-Kady (1989). Comparative study on some flax cultivars. Ann. Agric. Sci., Moshtohor, 27 (4): 2105-2120.

Hussein, E.M., M.T.M. Mansour, Maggie E.M. Hassan, Eman A. El-Kady and K.K. Kasem (2011). Use of serology, SDS-PAGE and RAPD analysis to evaluate resistance of flax to powdery mildew. Egypt. J. Agric., 89 (1): 17-34.

Hussein, M.M.M. (2012). Evaluation of productivity and quality for some local and introduced flax (Linum usitatissimum L.) varieties under different pulling dates in sandy soils. Minufiya J. Agric. Res., Vol. 37 No. 5 (1): $1171-1190$.

Leilah, A.A. (1993). Evaluation of yield and its components of flax cultivars under different nitrogen fertilizer levels. J. Agric. Sci., Mansoura Univ., 18 (2): 313-321.

Mahto, J.L., U. Choudhary and S.N. Singh (1995). Stability and genetic divergence in linseed (Linum usitatissimum L.) under rainfall situation. Ind. J. Agric. Sci., 65: 602-604.

Mansour, M.T.M. (1988). Pathological studies on powdery mildew of flax in A.R.E. Ph.D. Thesis, Zagazig Univ., Moshtohor, 148 p.

Mansour, M.T.M., Naglaa A. Ashry, A.A. Aly and S.M.E. Zayed (2003). Evaluation of some flax plant introductions for powdery mildew resistance under natural infection conditions. J. Agric. Sci., Mansoura Univ., 28 (4): 2689-2697. 
Momtaz, A., A.K.A. Salim and G.H. El-Shimy (1977). Correlation studies between flax seed yield and some other characters. Agric. Res. Rev., Egypt, 55: 45-55.

Mourad, N.K.M., H.M.H. Abo-Kaied, E.A.F. El-Kady, M.E.A. Kineber, Eman A.A. El-Kady, E.E. Lotfy, G.H. El-Shimy, Amna H.H. El-Sweify, S.H.A Mostafa, T.A. Abou-Zaied, I.E. El-Deeb and S.Z.A. Zedan (2009). Performance and stability of the new varieties "Giza 9" and "Giza 10". Egypt. J. App. Sci., 24 (11): 136-147.

Muskett, A.E. and J. Colhoun (1947). The Disease of "The Flax Plant". Northern Ireland Flax Development Committee. Belfast. 112 P.

Nutter, F.W., Jr. P.S. Teng and F.M. Shoks (1991). Disease assessment terms and concept. Plant Disease, 75: 1187-1188.

Nyvall, R.F. (1981). "Field Crop Diseases Handbook". AVI Publishing Company, Inc., Westport, Connecticut, 436 P.

Pandey, R.N. and D.D. Misra (1993). Assessment of yield loss due to powdery mildew of linseed. Indian Botanical Report, 11: 62-64.

Pearc, W.L., D.A. Van Sanford and D.E. Hersham (1996). Partial resistance to powdery mildew in soft winter wheat. Plant Disease 80: 1359-1362.

Perryan, A. and B. Fitt (2000). Effects of disease on the growth and yield of spring linseed (Linum usitatissimum, L.). Ann. Appl. Biol., 136 (3): 197207.

Radwan, S.R. and A. Momtaz (1966). The technological properties of flax fiber and method of estimating them. El-Felaha J. 46 (5): 466-476. (In Arabic).

Sharief, A.E. (1999). Performance of some flax cultivars in response to nitrogen fertilizer rates and yield analysis. Bull. Fac. Agric., Cairo Univ., 50: 394-415.

Zayed, S.M.E., T.A. Abou-Zaied and M.R. Omar (2008). Susceptibility of some flax genotypes to powdery mildew and effect of the disease on yield and yield components. J. Agric. Sci., Mansoura Univ., 33 (4): 2511-2520.

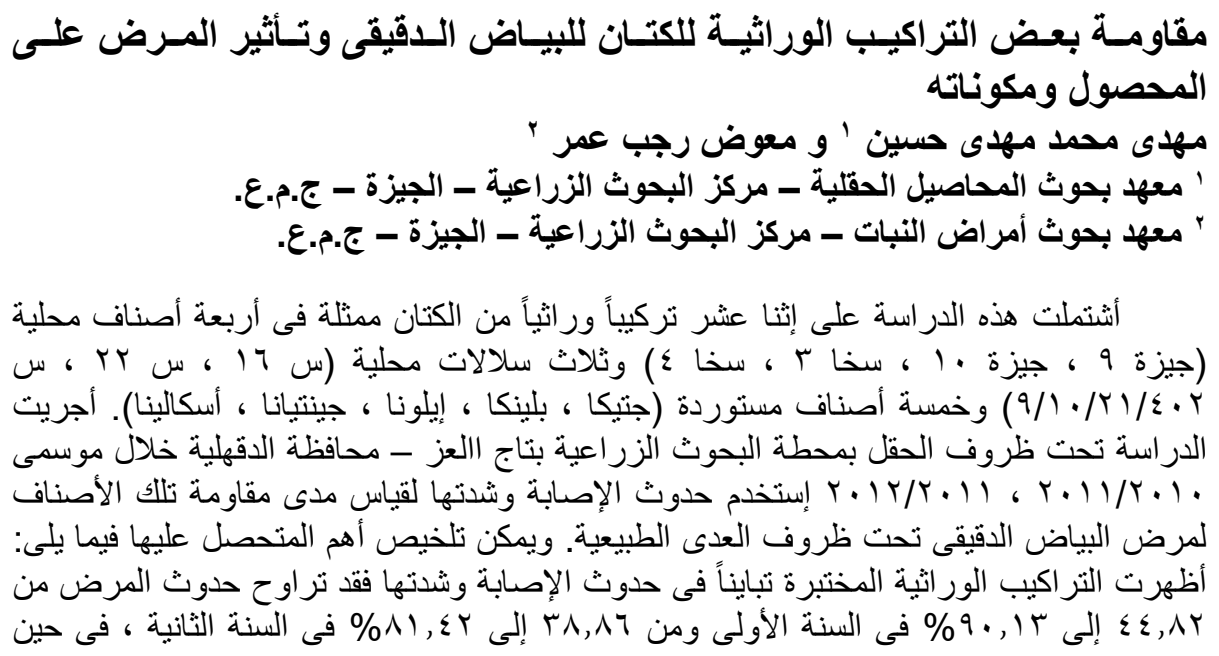




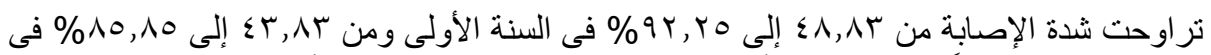

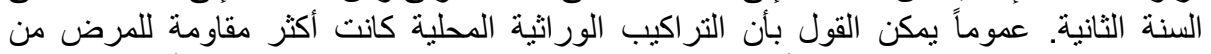

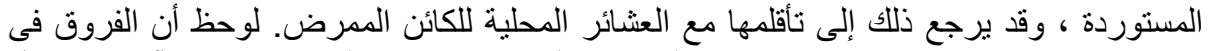

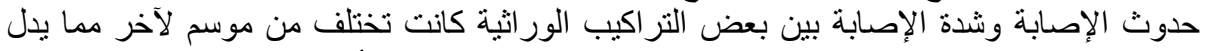

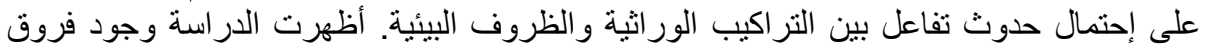

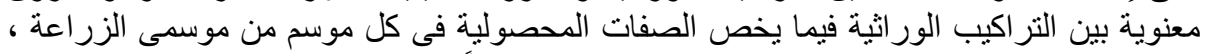

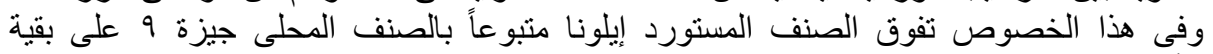

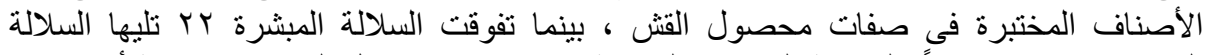

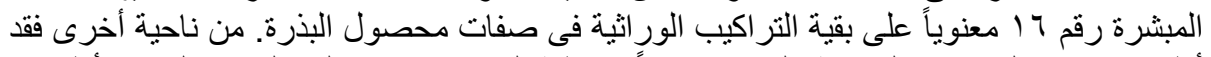

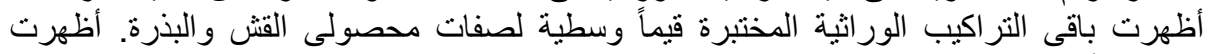

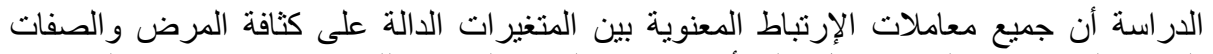

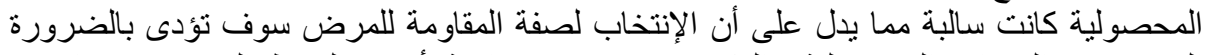

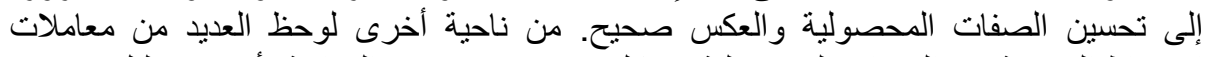

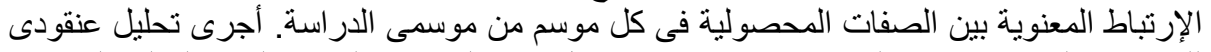

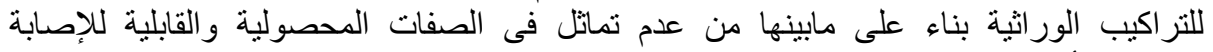

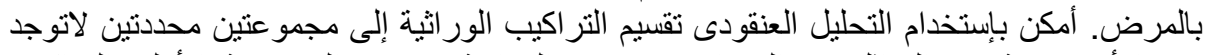

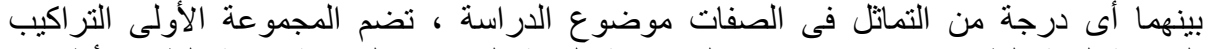

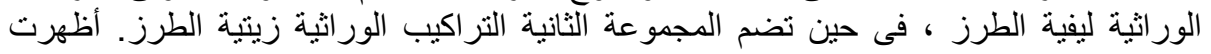

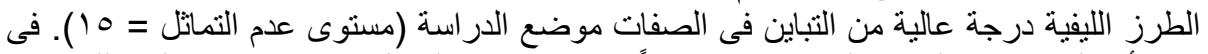

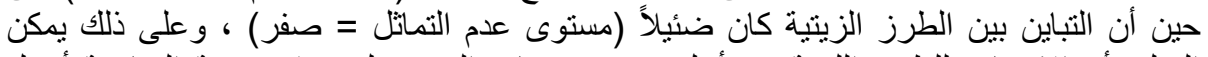

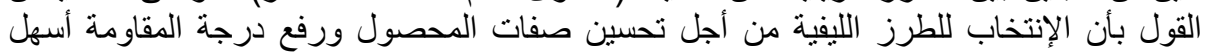
بكثير من الإنتخاب للطرز الزيخياب للطرز الزيفية.

\author{
كلية الزراعة - جامعة المنصورة \\ مركز البحوث الزراعية
}


J. Plant Production, Mansoura Univ., Vol. 4 (1), January, 2013 
Hussein, M. M. M. and M. R. Omer 
J. Plant Production, Mansoura Univ., Vol. 4 (1): 33 - 50, 2013

Table (6). Correlation coefficient for agronomic traits of twelve flax genotypes infected with powdery mildew under field conditions in Tag El-Ezz, El-Dakahlia 2010/2011 season.

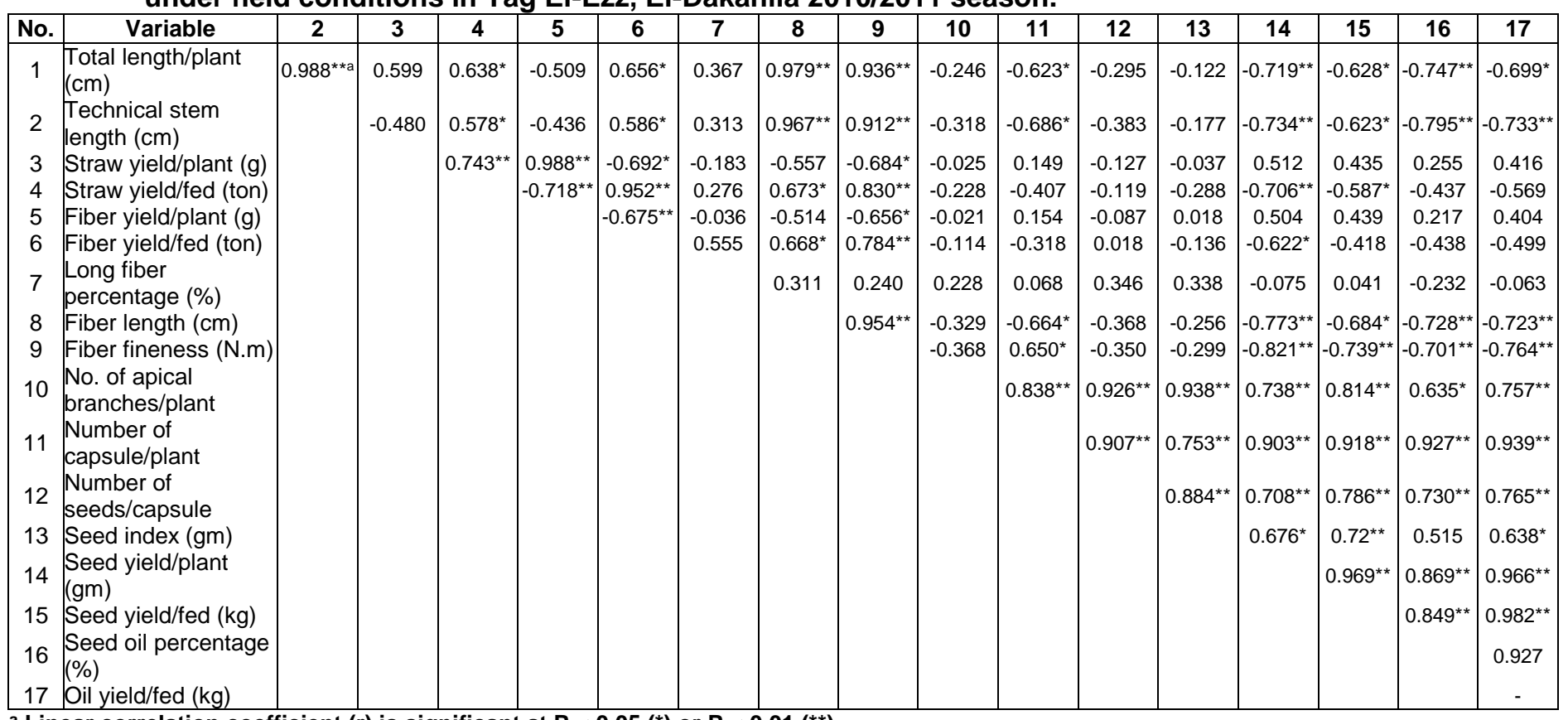

a Linear correlation coefficient $(r)$ is significant at $P<0.05\left(^{*}\right)$ or $P<0.01\left(^{\star *}\right)$. 
Hussein, M. M. M. and M. R. Omer

Table (7). Correlation coefficient for agronomic traits of twelve flax genotypes infected with powdery mildew under field conditions in in Tag El-Ezz, El-Dakahlia 2011/2012 season.

\begin{tabular}{|c|c|c|c|c|c|c|c|c|c|c|c|c|c|c|c|c|c|}
\hline No. & Variable & 2 & 3 & 4 & 5 & 6 & 7 & 8 & 9 & 10 & 11 & 12 & 13 & 14 & 15 & 16 & 17 \\
\hline 1 & Total length/plant & $0.983^{\star a}$ & $-0.631^{\star}$ & 0.555 & $0.769^{\star \star}$ & 0.401 & 0.454 & $0.966^{*}$ & $0.904^{\star *}$ & -0.476 & \begin{tabular}{|l|}
$\mid-0.367$ \\
\end{tabular} & 0.162 & $-0.749^{\star \star}$ & $-0.724^{\star *}$ & $-0.817^{\star \star}$ & $\left|-0.792^{* *}\right|$ & $-0.837^{*}$ \\
\hline 0 & Technical stem & & & & & & & & & & & & & & & & \\
\hline 2 & length $(\mathrm{cm})$ & & -0.552 & 0.523 & $-0.729^{\star \star}$ & 0.295 & 0.394 & $0.945^{\star \star}$ & $0.899^{\star *}$ & -0.509 & -0.415 & 0.102 & $-0.725^{\star \star}$ & $-0.707^{\star *}$ & $-0.828^{\star \star}$ & $-0.777^{\star \star}$ & $-0.790^{*}$ \\
\hline 3 & Straw yield/plant (g) & & & $-0.727^{\star \star}$ & $0.894^{\star *}$ & $-0.638^{*}$ & $-0.840^{* \star}$ & $-0.621^{*}$ & $-0.768^{\star \star}$ & 136 & -0.033 & -0.208 & $0.619^{*}$ & $0.559^{*}$ & 0.401 & 0.575 & $0.784^{\star \star}$ \\
\hline 4 & Straw yield/fed (ton) & & & & -0.669 & $0.791^{\star \star}$ & $0.891^{* *}$ & 0.566 & $0.798^{\star *}$ & 0.377 & -0.123 & -0.187 & $-0.752^{* *}$ & $-0.697^{*}$ & -0.453 & $-0.656^{\star}$ & $-0.597^{\star}$ \\
\hline 5 & Fiber yield/plant (g) & & & & & -0.555 & $-0.716^{* \star}$ & $-0.766^{* \star}$ & $-0.817^{* *}$ & 0.299 & 0.173 & -0.307 & $0.696^{*}$ & $0.938^{*}$ & $0.639^{*}$ & $0.683^{*}$ & $0.820^{* \star}$ \\
\hline 6 & Fiber yield/fed (ton) & & & & & & $0.852^{* *}$ & 0.357 & 0.507 & -0.016 & 0.243 & 0.244 & -0.460 & -0.361 & -0.211 & -0.366 & $\mid-0.566$ \\
\hline 7 & $\begin{array}{l}\text { Long fiber } \\
\text { percentage (\%) }\end{array}$ & & & & & & & 0.458 & 0.685 & -0.068 & 0.173 & 0.133 & -0.534 & -0.497 & -0.228 & -0.453 & $-0.618^{\star}$ \\
\hline 8 & Fiber length $(\mathrm{cm})$ & & & & & & & & $0.915^{\star *}$ & -0.428 & -0.319 & 0.042 & $-0.727^{\star *}$ & $-0.725^{* *}$ & $-0.732^{* *}$ & $-0.756^{\star *}$ & $-0.833^{*}$ \\
\hline 9 & Fiber fineness (N.m) & & & & & & & & & -0.515 & -0.346 & -0.047 & $-0.832^{\star \star}$ & $-0.836^{\star \star}$ & $-0.727^{\star \star}$ & $-0.831^{* *}$ & $0.826^{\star \star}$ \\
\hline 10 & $\begin{array}{l}\text { No. OI apical } \\
\text { branches/plant }\end{array}$ & & & & & & & & & & $0.931^{* *}$ & 0.556 & $0.820^{\star *}$ & $0.853^{* *}$ & $0.819^{* *}$ & $0.862^{\star *}$ & 0.055 \\
\hline 11 & $\begin{array}{l}\text { Number of } \\
\text { capsule/plant }\end{array}$ & & & & & & & & & & & 0.512 & $0.662^{*}$ & $0.713^{\star \star}$ & $0.716^{\star *}$ & $0.723^{\star \star}$ & -0.095 \\
\hline 12 & $\begin{array}{l}\text { Number of } \\
\text { seeds/cansule }\end{array}$ & & & & & & & & & & & & 0.342 & 0.389 & 0.168 & 0.288 & -0.401 \\
\hline 13 & Seed index (gm) & & & & & & & & & & & & & $0.976^{* *}$ & $0.875^{\star \star}$ & $0.981^{* *}$ & 0.501 \\
\hline 14 & $\begin{array}{l}\text { Seed yield/plant } \\
\text { (am) }\end{array}$ & & & & & & & & & & & & & & $0.834^{* *}$ & $0.982^{\star \star}$ & 0.446 \\
\hline 15 & Seed yield/fed $(\mathrm{kg})$ & & & & & & & & & & & & & & & $0.919^{* *}$ & 0.477 \\
\hline 16 & $\begin{array}{l}\text { Seed oil percentage } \\
(\%)\end{array}$ & & & & & & & & & & & & & & & & 0.494 \\
\hline 17 & Oil yield/fed $(\mathrm{kg})$ & & & & & & & & & & & & & & & & - \\
\hline
\end{tabular}

a Linear correlation coefficient $(r)$ is significant at $P<0.05\left(^{*}\right)$ or $P<0.01\left(^{\star \star}\right)$. 